\title{
Hacks and hackers: the ethos and beliefs of a group of Data-Driven Journalism professionals in Brazil
}

\author{
Repórteres e hackers: o ethos e as crenças de um grupo de profissionais de \\ Jornalismo Guiado por Dados no Brasil
}

Marcelo Träsel

Universidade Federal do Rio Grande do Sul (UFRGS)

$<$ marcelo.trasel@ufrgs.br $>$

\section{ABSTRACT}

The study is based on participant observation conducted among the staff of Estadão Dados, and also open interviews with individuals relevant to the formation and diffusion of this type of journalism in Brazil. The computational and network communication technologies are understood to be imbued with a hacker ethic, characterized by technophilia and cooperativism. As the logic of computer network communications is incorporated by journalists, these two typical values of the hacker spread to the journalistic professional culture, whose central ethical element is objectivism. Values of hacker culture were manifested clearly in the ethos of the observed Data-Driven Journalism specialists, whose duties require technical expertise and collaboration with professionals and fans in the field of computer science. The results of field research indicate that Data-Driven Journalism is one of the responses developed by journalists in reaction to economic and identity crises now facing contemporary journalism.

Keywords: Data-Driven Journalism. Ethnography. Hacker ethics.

\section{RESUMO}

O estudo é baseado em observação participante conduzida junto da equipe do Estadão Dados, bem como em entrevistas abertas com indivíduos relevantes para a formação e difusão deste tipo de jornalismo no país. As tecnologias computacionais e redes informáticas são imbuídas de uma ética hacker, caracterizada por tecnofilia e cooperativismo. À medida que a lógica da comunicação em rede é incorporada pelo jornalismo, esses dois valores típicos da figura do hacker se disseminam na cultura profissional jornalística, cujo elemento ético central é o objetivismo. Os valores da cultura hacker se manifestaram claramente no ethos dos profissionais de Jornalismo Guiado por Dados, cujas funções exigem conhecimento técnico e colaboração com profissionais e diletantes das ciências da computação. Os resultados sugerem que o Jornalismo Guiado por Dados é uma das respostas desenvolvidas pelos jornalistas em reação às crises econômica e identitária com as quais a profissão se depara contemporaneamente.

Palavras-chave: Jornalismo Guiado por Dados. Etnografia. Ética hacker.

Data-driven Journalism (DDJ) is a set of practices derived from the tradition of Computer-Assisted Reporting (CAR) and Precision Journalism (JP), which in the mid-2000s have been reinvigorated by the development of information technology and telecommunications, on the one hand, and the changes they precipitated in the industrial media model, on the other. DDJ is the application of computational and scientific techniques in the investigation, 
edition, publication and circulation of journalistic products, which may take the form of text, audiovisual, hypertext narratives, graphical visualizations, or news apps for the Web and mobile devices. These techniques are presented as a way to expand the capacity of journalism for investigation of social events and issues, aimed at fulfilling its accountability function (Schudson, 2003). Also, from the mid-2000s, the journalistic professional community has been adopting and promoting DDJ as a possible solution for economic and identity crises that unfolded in the media from the second half of the twentieth century on. This paper reports the results of a doctoral research focused on the ethos and beliefs of a group of Brazilian professionals dedicated to DDJ (Träsel, 2014a).

Rüdiger (2008) defines cyberculture as a manifestation of technological thinking in everyday life, of which the most important expression, for this study, is hacker ethic (Himanen, 2001; Coleman, 2013). This ethic is based on a predisposition to technophilia and cooperativeness, that is, the belief that machinery can solve all human problems, whatever their nature, and the valuing of sharing and transparency, expressed as the free flow of information. It imbues the computer of a collaborative spirit that is reflected in horizontal production practices and circulation of cultural goods (Bruns, 2005; Streeter, 2011). Digital journalism emerges in this context, and differentiates itself from television, radio or print journalism by the use of network communication platforms for news circulation and the incorporation of its interactive capabilities in production routines (Pavlik, 2001).

Marcondes Filho (2009) recalls the historical evolution of the press and media under a materialist perspective, pointing to how they maintain their humanistic character even after the adoption ofTaylorism in the newsrooms from the second half of the twentieth century. The professionalization of journalism has a technocratic character, which leads to standardization of verification procedures, writing and editing of news, in the name of journalistic objectivity, and to a increasingly redatorial and declaratory nature of news products (Neveu, 2009). From the 1990s, however, the economic crisis in the media accentuates (Anderson, Bell and Shirky, 2012; McChesney, 2013), deepening the identity crisis in which journalism had already been immersed since the 1970s, for the digitization of newsrooms causes tensions between the newspaper model and the new online journalism practices (Boczkowski, 2004). These new practices engender a new type of journalist, the Web producer (Anderson, 2012), whose workdays are restricted in general to the work in front of computer screens (Boyer, 2014). This bureaucratic screenwork conflicts with the journalist's myth as romantic hero (Lago, 2003), because it entails an abandonment of the gatekeeper function (Bruns, 2005), or central mediator of public information, 
for a seemingly more passive role of curator of flows of information produced by press offices, news agencies and citizen reporters.

One answer of the professional journalistic community to the economic and identity crises is DDJ, which promises to legitimize screenwork as a form of investigative reporting. As a professional practice, DDJ traces back to Meyer's (1973) JP proposal and the shy adoption of RAC in newsrooms during the 1980s and 1990s. Routinization of computers and the internet in the late twentieth century leads to an increase in the provision of public databases and inexpensive software to analyze them. Thus, there has been a resurgent interest in JP and RAC, particularly from the mid-2000s, when Holovaty (2006) published an influential article about collection and maintenance of databases in newsrooms. Based on authors who have studied DDJ, both professionals (Bradshaw, 2011; Gray, Chambers and Bounegru, 2012; Rogers, 2013; Silver, 2014) and academics (Parasie and Dagiral, 2013; Diakopoulos, 2012; Cohen, Hamilton and Turner, 2011; Lewis and Usher, 2013), one can express the concept of DDJ with which the journalistic professional community has been operating as: the application of computing and social science knowledge in the interpretation of data, with the aim of expanding the accountability enforcement role of the press as a defender of public interest. Underlying these proposals for the application of techno-science to production routines in newsrooms, however, is objectivism, a constituent of journalistic identity (Traquina, 2005). One could present a second formulation for the concept, including these theoretical aspects. DDJ would be, then, the application of techno-science to the productive routines of informative journalism, in a context of networked communication, in order to establish more solid claims of professional authority.

The concepts of ethos and belief operating here are those of Bourdieu, for whom ethos would be a number of provisions demonstrated by an individual, depending on the circumstances with which he is presented, and which, taken together, constitute his character - the latter being not a constitutive part of his personality, but a socially determined characteristic (Bourdieu 1980, p. 88). In this way, the concept of ethos confronts that of ethics, to the extent that ethics should be presented in a theoretical, reasoned, explicit and codified way. As for beliefs, in this paper they do not mean a conscious adherence of the individual to a system of values, dogmas and doctrines, but are presented as a practical sense, by which individuals orient their actions to achieve desired results from accumulated experience (Bourdieu, 1980, p. 115). Therefore, the term belief refers here to that practical sense, not to a particular ethical, religious or philosophical system. 


\section{Methodology}

This research follows Singer's (2008, p. 165) suggestion of an ethnographic approach of digital journalism comprising a triangulation of information sources, that is, the "process of using multiple perceptions to clarify meaning and identify different ways of seeing a phenomenon". In general, triangulation involves observation, interviews and questionnaires, but can include analysis of documents and other research techniques.

Estadão Dados ${ }^{1}$ (ED), the object of study, is a team created in 2012 in the newsroom of a major nationwide newspaper headquartered in São Paulo, whose assignment is to produce news from databases. It was the first group of data-driven journalists constituted as a newsroom desk in Brazil. The field research included 60 hours of participant observation distributed in ten days in July 2013, and open interviews with each member of ED. During this period, it was possible to record in the field diary the conduct and oral statements of team members, which were analyzed to identify their core beliefs and describe their professional ethos.

A total of eight external informants were interviewed. Although not related to ED, they were selected for their practical experience of DDJ, or because they were relevant actors in the development of this journalistic specialization in Brazil. The open interviews were conducted over years 2012 and 2013, in person. Another source of data was a pilot study, which included a period of participant observation of about 20 hours within a group of twelve trainee journalists and two editors, in a nationwide newspaper in Southeastern Brazil. The results of this pilot study were published in Träsel (2014b).

\section{Estadão Dados}

ED is an independent desk in the newsroom of Brazilian newspaper $O$ Estado de S. Paulo (Estadão), founded in 1875. Estadão had an average daily circulation of about 250,000 copies and 5,8 million unique visitors to it's website in February 2014. The team had four professionals at the time: José Roberto de Toledo, editor, Daniel Bramatti and Amanda Rossi, reporters - all three possessed BA degrees in journalism - and Diego Rabatone, software developer. The first task of ED was to develop the news Web application Basômetro ${ }^{2}$, which allows visualization of the behavior of parliamentarians of the House of Representatives in relation to the guidelines of the Executive branch for each of the votings

1 Available in: http://estadaodados.com.

2 Available in: http://estadaodados.com/basometro. 
that were held since 2011. The accumulation of results generates a "governism index" for each representative or senator. For example, a representative who votes $90 \%$ of times as directed by the federal government will have assigned to her a higher fidelity index than a parliamentarian whose votes conform to the guidelines of the presidency in only $50 \%$ of occasions.

Another important project is Estadão Dados Blog ${ }^{3}$, whose goal is to publish a daily data visualization. There the readers can "find graphics and animations on topics of the day's news, as well as data mash-ups and special analyses made by our team of journalists and programmers". According to Toledo, the purpose of the weblog is to exercise the team's ability to establish relationships between different kinds of data and inspire reportage ideas for the other desks in Estadão:

\begin{abstract}
To do this every day is not easy, it's more complicated than it looks, but fortunately we have been managing to maintain daily regularity since the blog was created and I think it is having many positive effects, because the idea of publishing these infographics, beyond serving as an exercise of journalists and staff, it's also to create guidelines for the newspaper, and this has been done very successfully. Many infographics we published have become important articles in several different desks, we managed to diversify our range of customers, so to speak, and instill in the rest of the newsroom journalists an interest to work these databases and generate journalistic material from them (Toledo, 2013).
\end{abstract}

Examples of collaboration between ED and other newsroom desks are a graph showing the transformation of domestic work in the decade from 2003 to 2013, which followed a special report of Estadão on the "Law of Domestic Employees", produced by the editors of Economics; an analysis of the reduction of homicides in the city of São Paulo on weekends, produced for the Metropolitan desk; and the discovery that the adoption of the 9th grade in elementary school created a class of students that lagged behind other classes in the state capital, published in the Education section of the print newspaper.

In August 2013, ED started to collaborate with the journalist Lucas Abreu Maia, who was returning from a Master's course in Public Opinion at the University of Chicago. During the course, the reporter learned statistical techniques and began to apply them in the production of news within the newsroom. The first report for which he has developed a specific statistical model was about the relationship between infant mortality and socio-economic factors. Through a

3 Available in: http://blog.estadaodados.com. 
multivariate linear regression, he identified the factors with greater explanatory power for infant mortality rate and isolated as the most significant variable the literacy level of parents.

\section{Technophilia, cooperativeness and objectivism}

Field research revealed two characteristics that seem specific of datadriven journalists: the beliefs in cooperativeness and technophilia typical of hacker culture. On the other hand, these professionals demonstrate a strong connection with the conventional journalistic identity, foremost through valuing of objectivity.

Considering the competitive character trait by which the journalist figure is popularly known, the tendency to share information shown by ED staff becomes intriguing. Basômetro, for example, was developed with reasonable technical and journalistic effort, the result of months of dedication from journalists and programmer. Although they could keep that tool restricted, as a system for monitoring the Brazilian Congress with the goal of generating story ideas inaccessible to competing newspapers, ED allowed anyone to access Basômetro. Even graphical analyses published daily in ED's weblog could guide the production of stories by competitors, as much as they point to newsworthy statistical relationships.

Apart from external competition, there is often an internal competition among journalists in the newsroom, since reporters and editors compete to climb positions in the company hierarchy and achieve prestige. Although they commemorated when they made the print headlines or published scoops, ED members appeared not to see that kind of success as a way to conquer space from other teams within Estadão. In fact, they tended to see themselves as consultants or service providers dedicated to collaborating with other journalists to improve the quality of news produced by the whole newsroom.

But I think the blog has a different role, it is not simply an informational medium, I think it is also an educational medium in the sense of establishing a culture of data, a data journalism culture, visualization, right? It's about journalists trying to read, understand this material and build stories on top of that, about experts also having a data source and information that's more, more crude, coming from a medium of mass communication (Rabatone, 2013). 
This passage highlights the role of knowledge diffusers undertaken by ED members. They see themselves as a vanguard of DDJ in Brazil, imbued with the responsibility to improve the quality not only of journalism in Estadão, but nationally, through the dissemination of these practices.

Cooperativeness also manifests itself as adherence to the transparency value of hacker ethic. An example is the licensing of Basômetro source code under GPL, which allows not only reproduction, but also a detailed review of the conceptual assumptions and mathematical models used in its manufacture. This adherence to information sharing values typical of the Free and Open Source Software (F/OSS) community is a strong indication of rapprochement between professional journalistic culture and hacker culture among the group.

A second relevant aspect in the ethos of data-driven journalists is technophilia, i.e., the affinity for manipulation and understanding of technical artifacts. While hardware such as smart phones have earned consideration in some dialogues between members of the ED and of those with the researcher, most technical discussions revolved around features and uses of different types of software. Not only were these dialogues brought up to weigh the effectiveness of different tools for everyday tasks of ED, but the team also debated the qualities of various applications in a playful way, to socialize and unwind during pauses in the work day.

Three of the four members of ED at the time could be described as passionate about computers: Toledo, Bramatti and Rabatone. The ED team was not, however, a group that used and produced technology uncritically. The term technophilia, here, has not the pejorative meaning of a disposition of the spirit that prevents reasonable judgment of technical devices, but refers to personal affinity for these objects. Indeed, the very F/OSS movement, despite the passion for technology that characterizes its members, is engendered by a political questioning of the role of technology in society (Streeter, 2011).

Rabatone declared himself a hacker and stated he sees elements of the same ethic in his teammates:

I think every journalist has a little bit of the hacker spirit, from the point of view that... Yes, one of the most important things is the question of curiosity within the hacker culture. And I find it hard for someone to be a journalist without curiosity, without being a curious person who goes after things, tries to understand how an information, a reality, works. I think everyone has a little, some portion, but the journalist more than other [people], maybe. I think even within the journalistic culture they are beyond, you know, always trying to 
understand a new tool, know it a little better... Not just staying within the language of the journalist, but trying to understand the side of the programmer and the developer as well. I can expose technical difficulties minimally, and then we begin to work on top of that, everyone together. So I think, yes, I think we should consider them a bit as hackers (Rabatone, 2013).

In the assessment of the team programmer, ED members share some identifying features of technophile culture more than other journalists. His colleagues made a point of denying themselves hacker status, but observation of daily activities showed they adopted work strategies and adhered to values that are part of hacker ethic. One example was their strategy for assimilation of new tools in professional and personal life, which was characterized by self-education bolstered with resources available on the Web (Träsel, 2014c). Moreover, in their biographies were common the attendance in short courses taught by experts - presential or at distance - and mentoring by other journalists experienced in working with data, especially in the context of internships during college or early career.

This self-taught approach to learning is one of the most typical features of hacker culture (Himanen, 2001; Coleman, 2013), whose adherents tend to a hedonistic appropriation of technology. Members of ED improvise with databases that appear in their daily routines, adopting and abandoning tools at the whim of necessity. Unlike staff in other desks of Estadão, whose journeys were also mostly comprised of screenwork, but restricted to the use of applications determined by Information Technology sector, ED members used their own computers, which let them install and uninstall programs at ease. In this sense, screenwork performed by ED journalists presents a greater variation than the screenwork of reporters stationed in more traditional functions, whose routines have been described by Boyer (2014).

Although screnwork is the norm for virtually all contemporary journalists, there seems to be a difference of autonomy from the machines among professionals stationed into common functions of reporting, editing, design and layout, and the group of informants observed during field research. While some, regardless of their individual expertise in information technology, are chained to bureaucratic decision-making processes about the software and hardware they will have access to, others dominate all technical instances related to their functions, from the Internet connection provider to the server on which their stories are stored. 
The last character trait bespoken by participant observation was a strong adherence to the journalistic value of objectivity among ED members. The concept of objectivity, understood primarily as impartiality or neutrality, has been questioned no only by movements such as Literary Journalism, but also by investigative reporters, who claim for themselves, in some cases, the condition of "unobjective" or "partial" Lanosga (2012, p. 42). Lanosga considers that this claim would point not to a rejection of objectivity alltogether, but for an alternative way to perform it, in which the objective character of a story would derive from exposure of evidence in the form of documents, statements, denouncement of deviant behaviors, or even systematic descriptions of relationships between people and events that lead to conclusions about the occurrence of illegalities. It is precisely the latter type of evidence that is produced by analysis and visualization of data. While mashing up databases can evince the existence of relationships between people and suspicious events in succession, the materialization of these findings in graphical visualizations makes it easier to understand complex connections. The exposition of a succession of facts and relationships between data and social actors - a journalistic narrative - suffices as evidence for the reporter and the reader, if logically sound.

This is the sense of Meyer's (2004, p. 54) argument that "true objectivity is based on method, not result". Instead of merely following a strategic ritual (Tuchman, 1978) in submitting statements of social actors, as if all the utterances were equivalent in terms of truth, the real investigative reporter, from the perspective of JP, should strive to evaluate contradictory views, giving them due weight through use of the scientific method, in order to avoid being cheated by her own prejudices and values. The goal of objectivity in DDJ, therefore, is to move away from declaratory news, in which two or more sources present contradictory statements without an evaluation by the reporter, to a journalism in which objectivity is established by contrast between statements and available data about a particular topic.

Recalling his initiation into DDJ, Toledo expressed this view:

After that, I went to the political notes section and was six years doing that in Folha. This was a period of extreme learning, because I had to deal with a very large amount of politicians daily, but also a period of exhaustion of that traditional political coverage, for it was no longer even coverage of phrasing, of declaratory journalism, but coverage of backstage, which is very fluid, always difficult to check, to verify. I had an obsession for not publishing anything I could not check with another source, what had a good side and made me more secure with what I [...], but I lost much stuff. Perhaps most of the information that 
reached us could not be checked with another source, as it is not a very tangible thing. Perhaps traumatized by this experience, when I asked to leave the notes, after six years, and went to the special reporting desk, I dedicated myself to absolutely concrete things, that I could easily verify and were demonstrable, [which] were closer to what we might call the precision or scientific journalism (Toledo, 2013).

Participant observation revealed that the members of ED believe in DDJ practices as a way to produce a news coverage more efficient in serving the public interest. This efficiency would happen first by abandonment of human sources in favor of databases, an ideal that echoes Parasie and Dagiral (2013). This shift in focus would attribute greater veracity to news, by presenting numbers and graphs. Second, DDJ opens the possibility of performing investigations at low cost, in a context of scarce resources in the contemporary press, for it is possible to find information from a computer in the newsroom, rather than move a team to, for instance, the Amazon, to check for possible illegal deforestation.

\section{Conclusion}

Combination of participant observation of Estadão Dados, interviews and document analysis revealed as main elements of the ethos of data-driven journalists: cooperativeness, technophilia and objectivism.

Technophilia manifests as the belief in the computer's ability to eliminate human error of journalistic production routines. First, data collection and analysis would allow an improvement of news gathering by reporters, who, using numerical analysis tools, could establish a more solid factual basis, from the point of view of objectivity, to interpret events. Second, machinisms also possibilitate a reduction in deviations of human cognition on the audience side, by presenting complex relationships between data in the form of data visualizations or applications, thus facilitating their understanding. Third, focus on data counteracts the misconceptions and distortions introduced by human sources during the process of verification, who, although still being consulted and cited in stories, should do it from previous findings from reporters. In other words, rather than framing the news, sources would react to frames developed by the initiative of newsrooms.

Cooperativeness manifests itself primarily on adherence to the values of transparency and sharing in DDJ practices. In submitting databases, statistical models and explaining analytical procedures, journalists invite the public to carry out an audit of the whole process and its results, pointing out errors 
and adding relevant information. At the same time, they cede control over the narrative, to the extent that licensing of databases for readers helps them to perform their own interpretations and modify the presentation formats of the resulting information. There is potential for multiplying the value of databases as public goods, since they can be reused in various ways by many different actors in the media ecosystem, as it happens in the F/OSS model of software development. A second important form of manifestation of cooperativeness is sharing of knowledge on DDJ techniques and data sources, by publishing tutorials, delivering courses, or establishing learning relationships between veterans and beginners.

Post-humanist elements of Cyberculture (Rüdiger, 2008) show clearly in the technophile trend ofDDJ practitioners suggesting the replacement of human sources for databases, a move that, in their view, would ensure the overcoming of declaratory journalism on behalf of a renewed objectivity. Cooperativeness appears among this professional group as a rapprochement with hacker ethic, which leads one to wonder the possibility that contact with technology and programmers in newsrooms is promoting an exchange of values and beliefs between journalists and hackers. However, cooperativeness and technophilia, emerging as new values in journalistic professional identity, are subordinated to its objectivism.

Replacement of human sources by numerical sources and transparency practices contribute to the repositioning of objectivity as the central value in journalistic culture. While data analysis and visualization allow journalists to reclaim impartiality, the adoption of sharing and transparency practices, by relinquishing control of narratives to the reader, at the same time delegates interpretation of numbers to the audience. One of the advantages of objectivity, in the journalistic view, is to separate information and opinion, allowing the newsroom to escape from ideological disputes. However, to the extent that news stories are narratives constructed by journalists, they are always susceptible to ideological scrutiny by sources and readers. Social actors involved in news events and people whose political, religious, and cultural beliefs are confronted by a story can always question the ideology of its author, as written language takes part in some order of discourse. Numbers and data visualizatons, while being socially constructed just as other forms of discourse, are often seen as ideologically neutral entities (Porter, 1995). Thus, in offering the possibility of searching a database - presenting the evidences - journalists can transfer responsibility for the resulting interpretations to the reader, keeping the aura of objectivity for themselves, the audience and the sources. 


\section{REFERENCES}

ANDERSON, Christopher W. Breaking journalism down: Work, authority, and networking local news, 1997-2009. 2009. 328 f. Tese (Doutorado em Comunicação Social) - Columbia University, Nova York, 2009.

ANDERSON, Christopher W.; BELL, Emily; SHIRKY, Clay. Jornalismo pós-industrial: adaptação aos novos tempos. Revista de Jornalismo ESPM, n. 5, abr./jun. 2013.

BOCZKOWSKI, Pablo. Digitizing the news: innovation in online newspapers. Cambridge: MIT Press, 2004.

BOURDIEU, Pierre. Le sens pratique. Paris: Editions de Minuit, 1980.

BOYER, Dominic. The life informatic: newsmaking in the digital era. Ithaca: Cornell University Press, 2014. [Ebook].

BRADSHAW, Paul. The inverted pyramid of data journalism. Online Journalism Blog, 7 jul. 2011a. Disponível em: http://onlinejournalismblog.com/2011/07/07/theinverted-pyramid-of-data-journalism. Acesso em: 25 fev. 2013.

BRUNS, Axel. Gatewatching: collaborative online news production. Nova York: Peter Lang, 2005.

COHEN, Sarah; HAMILTON, James T.; TURNER, Fred. Computational journalism. Communications of the ACM, v. 54, n. 10, 2011, p. 66-71. Disponível em: http:// cacm.acm.org/magazines/2011/10/131400-computational-journalism/fulltext. Acesso em: 16 jul. 2013.

COLEMAN, E. Gabriella. Coding freedom: the ethics and aesthetics of hacking. Woodstock:Princeton University Press, 2013. Disponível em: http://beforebefore. net/136c/s16/media/coleman.pdf. Acesso em: 4 set. 2017.

DIAKOPOULOS, Nicholas. Cultivating the landscape of innovation in computational journalism. City University of New York, abr. 2012. Disponível em: http://cdn. journalism.cuny.edu/blogs.dir/418/files/2012/04/diakopoulos_whitepaper_ systematicinnovation.pdf. Acesso em: 10 mai. 2013.

GRAY, Jonathan; CHAMBERS, Lucy; BOUNEGRU, Liliana (orgs.). The data journalism handbook: how journalists can use data to improve the news. Sebastopol: O'Reilly, 2012.

HIMANEN, Pekka. The hacker ethic and the spirit of the information age. Nova York: Random House, 2001.

HOLOVATY, Adrian. A fundamental way newspaper sites need to change. Adrian Holovaty, 6 set. 2006. Disponível em: http://www.holovaty.com/writing/ fundamental-change. Acesso em: 17 fev. 2013. 
LAGO, Cláudia. O Romantismo Morreu? Viva o romantismo! Ethos romântico no jornalismo. 2003. 227 f. Tese (Doutorado em Ciências da Comunicação) - Escola de Comunicação e Artes, Universidade de São Paulo, São Paulo, 2003.

LANOSGA, Gerry. A new model of objectivity: investigative reporting in the twentieth century. In: SAINT JOHN, Burton; JOHNSON, Kirsten (orgs.). News with a view: essays on the eclipse of objectivity in modern journalism. Jefferson: McFarland \& Company, 2012.

LEWIS, Seth; USHER, Nikki. Open source and journalism: toward new frameworks for imagining news innovation. Media, culture \& society, v. 35, n. 5, p. 602-619, 2013. DOI: https://doi.org/10.1177/0163443713485494.

MARCONDES FILHO, Ciro. Ser jornalista: o desafio das tecnologias e o fim das ilusões. São Paulo: Paulus, 2009.

MCCHESNEY, Robert. Digital disconnect: how capitalism is turning the Internet against democracy. Nova York: The New Press, 2013. Disponível em: https:// www.amazon.com/Digital-Disconnect-Capitalism-Internet-Democracy/ dp/1595588671. Acesso em: 4 set. 2017.

MEYER, Philip. Precision Journalism: a reporter's introduction to social science methods. Bloomington: Indiana University Press, 1973.

MEYER, Philip. The next journalism's objective reporting. Nieman Reports, n. 58, 2004. Disponível em: http://www.nieman.harvard.edu/reports/article/100726/TheNext-Journalisms-Objective-Reporting.aspx. Acesso em: 27 fev. 2014.

NEVEU, Erik. Sociologia do jornalismo. São Paulo: Loyola, 2006.

PARASIE, Sylvain; DAGIRAL, Éric. Des journalistes enfin libérés de leurs sources? Promesse et réalité du "journalisme de données". Sur le journalisme, v. 2, n. 1, 2013.

PAVLIK, John. Journalism and new media. Nova York: Columbia University Press, 2001.

PORTER, Theodore. Trust in numbers: the pursuit of objectivity in science and public life. Princeton: Princeton University Press, 1995.

RABATONE, Diego. Interview conducted by the author in 29 Jul. 2013.

ROGERS, Simon. Facts are sacred. Londres: Faber and Faber, 2013. Disponível em: https://www.downloadgeek.com/download/book/Facts+are+Sacred\%3A+Th e+Power+of+Data.html?aff.id=1496\&aff.subid=12. Acesso em: 4 set. 2017.

RÜDIGER, Francisco. Cibercultura e pós-humanismo: exercícios de arqueologia e criticismo. Porto Alegre: EdiPUCRS, 2008. 
SCHUDSON, Michael. The sociology of news. Nova York: Norton, 2003.

SILVER, Nate. The signal and the noise: why so many predictions fail but some don't. Nova York: Penguin, 2012.

SINGER, Jane B. Ethnography of newsroom convergence. In: PATERSON, C.; DOMINGO, D. Making online news: the ethnography of new media production. Nova York: Peter Lang, 2008.

STREETER, Thomas. The Net Effect: Romanticism, Capitalism, and the Internet. Nova York: New York University Press, 2011.

TOLEDO, José R. de. Interview conducted by the author in 29 Apr. 2013.

TRAQUINA, Nelson. Teorias do jornalismo: a tribo jornalística - uma comunidade interpretativa transnacional. V. 2. Florianópolis: Insular, 2005.

TRÄSEL, Marcelo. Entrevistando planilhas: estudo das crenças e do ethos de um grupo de profissionais de jornalismo guiado por dados no Brasil. 2014. $314 \mathrm{f}$. Tese (Doutorado em Comunicação Social) — Faculdade de Comunicação Social, Pontifícia Universidade Católica do Rio Grande do Sul, 2014a.

. Jornalismo guiado por dados: aproximações entre a identidade jornalística e a cultura hacker. Estudos em Jornalismo e Mídia, v. 11, n. 1, 2014 b.

. Aprendendo a se deixar guiar por dados: a formação dos jornalistas da equipe Estadão Dados. Revista Brasileira de Ensino de Jornalismo, Brasília, v. 4, n. 14, p. 85-99, jan./jun. 2014c.

TUCHMAN, Gaye. Making news: a study in the construction of reality. Nova York: The Free Press, 1978.

Departamento de Comunicação da Faculdade de Biblioteconomia e Comunicação da Universidade Federal do Rio Grande do Sul (UFRGS)

Rua Ramiro Barcelos, 2.705 - Bairro Santana

90035-007 - Porto Alegre (RS) - Brasil 